\title{
NOTE
}

\section{Inheritance of resistance to the Papaya ringspot virus-watermelon strain (PRSV-W) from watermelon accession 'PI 595201'}

\author{
Sebastião Márcio de Azevedo ${ }^{1}$, Wilson Roberto Maluf ${ }^{2}$, Marcos Ventura Faria ${ }^{3 *}$, Juliano Tadeu Vilela de Resende ${ }^{3}$, \\ Cícero Beserra de Menezes ${ }^{4}$ and Ildon Rodrigues do Nascimento ${ }^{5}$
}

\begin{abstract}
Two watermelon genotypes were used as parental in crosses designed to study the inheritance of resistance to PRSV-W: the cultivar Crimson Sweet (susceptible) and the accession 'PI 595201'(resistant). Plants of the generations $P_{1}, P_{2}, F_{1}, F_{2,} B C_{11}$ e $B C_{12}$ were inoculated with a Brazilian isolate of $P R S V$ - $W$ and were evaluated by recording symptoms. Genetic and phenotypic parameters of PRSV-W resistance were estimated and tests based on hypothesis of monogenic inheritance and maximum likelihood methods were performed. The additive component [a] of resistance was higher than the non-additive [d]. The estimates of the broad-sense heritability (0.80) and of narrow-sense heritability (0.67) indicated that the genetic variance was greater than the environmental, allowing higher genetic gains in selecting more resistant plants in segregating populations. The inheritance is more complex than a typical monogenic inheritance. The importance of the additive genetic effects in the expression of resistance to PRSV-W was evidenced.
\end{abstract}

Key words: Citrillus lanatus, degree of dominance, heritability, potyvirus, virus resistance.

\section{INTRODUCTION}

Papaya ringspot virus-watermelon strain (PRSV$\mathrm{W}$, formerly Watermelon Mosaic Virus-1=WMV-1) is a potyvirus that affects all of the cultivated species of Cucurbitaceae, achieving great economic importance because of its destructiveness. The virus is transmitted in a non-persistent manner by numerous species of aphids, including Myzus persicae and Aphis spp. (Bateson et al. 2002). It has become one of the most limiting pathogens to cucurbit crops in warm climate countries as Brazil, where aphids can easily survive throughout the year. Symptoms vary from chlorotic spots and mosaic to distortions, mainly in apical leaves. Flower malformation and fruit inhibition can be observed as well. More severe symptoms on fruit are caused by the virus as responsible of high economic damage

Virus incidence is related to aphid population density. Strategy to limit PRSV-W infection is the use of insecticides to eliminate the virus vectors. However, before insecticide treatment become effective, aphids may still be able to transmit the virus. Chemical treatments and light-reflective mulches also proved to

\footnotetext{
${ }^{1}$ Sakata Seed Sudamerica, Av. Plínio Salgado 4320, 12.902-001, Bragança Paulista, SP, Brazil

${ }^{2}$ Universidade Federal de Lavras, Departamento de Agricultura, Campus Universitário, 37.200-000, Lavras, MG, Brazil

${ }^{3}$ Universidade Estadual do Centro Oeste, Departamento de Agronomia, Campus CEDETEG, 85.040-080, Guarapuava, PR, Brazil.*E-mail:mfaria@unicentro.br

${ }^{4}$ Embrapa Milho e Sorgo, Rod. MG 424, km 45, 35.701-970, Sete Lagoas, MG, Brazil

${ }^{5}$ Universidade Federal do Tocantins, Campus de Gurupi, 77.410-080, Gurupi, TO, Brazil
} 
SM Azevedo et al.

be inefficient for viral disease control. Cross protection with mild strains of the virus has been tested with some success (Rezende and Pacheco 1998), but it needs further studies to be recommended to farmers, due to possible synergistic effect when the plants are infected by more than one virus. Genetic resistance is the ideal virus control strategy (Fraser 1992), both economically and environmentally.

Accessions with PRSV-W resistance have been identified in many cucurbit crops, inheritance mechanisms have been elucidated, and resistant cultivars have been released (Maluf and Sousa 1984, Wang et al. 1984, Maluf et al. 1985). PRSV-W resistance is controlled by a single dominant gene in cucumber (Wai and Grumet 1995) and a single dominant gene in melon (Pitrat and Lecoq 1983). In C. maxima resistance to PRSV-W is controlled by three partially-dominant genes (Maluf et al. 1997).

However, PRSV-W resistance studies in watermelon are fewer than in other cucurbit species. Strange et al. (2002) performed the most extensive screening of watermelon germplasm collection from the USDA and reported PRSV-W resistance in three PI accessions from South Africa (PI 244017, PI 244018, PI 244019), in three PI accessions from Zimbabwe (PI 482342, PI 482318, PI 482379), one accession from Botswana (PI 485583) and one accession from Nigeria (PI 595203). All of the resistant accessions except PI 595203 are C. lanatus var. citroides, whereas PI 595203 is C. lanatus var. lanatus. Araújo and Souza (1988) identified the watermelon accession 'Ouricuri' as a source of PRSV-W resistance. This line was used in crosses with the susceptible cultivar Charleston Gray, and a resistant line was subsequently obtained. Hojo et al. (1991) identified an African bitter-fruited watermelon accession BT-8501 that was supposed to be resistant to PRSV-W, based on absence of leaf symptoms after mechanical viral inoculation. Leaf crude extract of the symptomless 'BT-8501' inoculated onto susceptible Cucurbita pepo 'Caserta' produced marked viral disease symptoms, indicating that 'BT-8501' probably induces a tolerant reaction type to PRSV-W infection. Nascimento et al. (2011) reported a high level of resistance in the accession PI 595201 to an isolate of PRSV-W from watermelon producer regions of the state of Tocantins, Brasil. No reports on the mode inheritance of PRSV-W resistance were made in any of these studies.
In preliminary studies, made at the Universidade Federal de Lavras- UFLA, Lavras-MG, Brazil, a number of watermelon accessions were released as being resistant to the related potyvirus Watermelon Mosaic Virus (WMV). One of these lines - PI 595201- was also resistant to PRSV-W. The mode of inheritance of this resistance was not previously known, and is reported in this paper.

\section{MATERIALS AND METHODS}

\section{Plant material}

The experiments were performed at the Universidade Federal de Lavras, Lavras, MG, Brazil (lat $21^{\circ} 13$ ' $17^{\prime}$ ' S, long 45 $57^{\prime} 47^{\prime \prime} \mathrm{W}$ and alt $918 \mathrm{~m}$ asl) in the summer of 2000. Two watermelon [Citrillus lanatus (Thunb.) Matsum. and Nakai] genotypes were used as parental in crosses designed to study the inheritance of PRSV-W resistance: the cultivar Crimson Sweet, traditionally cultivated in Brazil and susceptible to PRSVW) and 'PI 595201', a not marketable accession resistant to PRSV-W obtained from USDA - US Vegetable laboratory, Charleston, SC, USA.

The $\mathrm{F}_{1}$ generation were obtained by controlled pollinations among the two parents, Crimson Sweet $\left(\mathrm{P}_{1}\right)$ and PI $595201\left(\mathrm{P}_{2}\right)$, and $\mathrm{F}_{1}\left(\mathrm{P}_{1} \times \mathrm{P}_{2}\right)$ plants were subsequently selfed and backcrossed to both parents in order to obtain generations $\mathrm{F}_{2}, \mathrm{BC}_{11}\left(\mathrm{~F}_{1} \times \mathrm{P}_{1}\right)$ and $\mathrm{BC}_{12}\left(=\mathrm{F}_{1} \times \mathrm{P}_{2}\right)$.

\section{Viral isolate and inoculation procedures}

A Brazilian isolate of PRSV-W (identified at the Department of Plant Pathology of Universidade Federal de Lavras, Lavras, MG, Brazil) was maintained in plants of Cucurbita pepo cultivar 'Asmara' in a greenhouse. Inoculum was obtained from these plants showing severe mosaic and foliar deformations, by maceration of symptomatic leaves $(10 \mathrm{~g})$ in $90 \mathrm{ml}$ of $0.01 \mathrm{M}$ phosphate buffer pH 7.0 with $0.1 \%$ sodium sulfite (Della Vecchii and Ávila 1985, Maluf et al. 1985, Oliveira et al. 2003).

Plants of the generations $\mathrm{P}_{1}, \mathrm{P}_{2}, \mathrm{~F}_{1}, \mathrm{~F}_{2}, \mathrm{BC}_{11}$ e $\mathrm{BC}_{12}$ were grown in styrofoam trays filled with a commercial substrate mix. First inoculation was made on the cotyledonary leaves of watermelon plants previously sprayed with 400 mesh carborundum, and a second inoculation was performed 5 days later on true leaves. 


\section{Evaluation of plant symptoms to PRSV-W}

After inoculations the plants were transplanted to the field, spaced $1.0 \mathrm{~m} \times 0.8 \mathrm{~m}$. The different generations were placed in a completely randomized design with three replications, each one with 30 plants of $\mathrm{P}_{1}, 30$ plants of $\mathrm{P}_{2}, 30$ plants of $\mathrm{F}_{1}, 200$ plants of $\mathrm{F}_{2}, 60$ plants of $\mathrm{BC}_{11}$ and 60 plants of $\mathrm{BC}_{12}$.

Plants were evaluated by recording symptoms starting 35 days after the first inoculation, and repeated at two subsequent 7 day intervals (42 and 49 days after first inoculation). Severity of viral symptoms of each plant was rated using a scale from 1 to 5 (adapted from Oliveira et al. 2003), as follows: $1=$ no visible symptoms; $2=$ majority of leaves with mild symptoms, mostly vein clearing or sparse chlorotic spots; $3=$ majority of leaves with mosaic; symptoms varying from vein clearing to sparse chlorotic spots to chlorosis in up to $50 \%$ of the leaf area; $4=$ almost all leaves with severe mosaic; coalescence of chlorotic areas, reaching up to $50 \%$ of the leaf area; $5=$ almost all the leaves with severe mosaic; at least one leaf with more than $50 \%$ of its area affected or severely distorted.

\section{Estimates of genetic and phenotypic parameters}

Means and variances of score data obtained from $\mathrm{P}_{1}, \mathrm{P}_{2}, \mathrm{~F}_{1}, \mathrm{~F}_{2}, \mathrm{BC}_{11}$ e $\mathrm{BC}_{12}$ were used to estimate genetic $\left(\hat{\sigma}_{G}^{2}\right)$, enviromental $\left(\hat{\sigma}_{\mathrm{E}}^{2}\right)$, phenotypic $\left(\hat{\sigma}_{\mathrm{F} 2}^{2}\right)$, additive $\left(\hat{\sigma}_{\mathrm{A}}^{2}\right)$ and dominance $\left(\hat{\sigma}_{\mathrm{D}}^{2}\right)$ variances, and estimates of broadsense $\left(\mathbf{h}_{\mathrm{b}}^{2}\right)$ and narrow-sense $\left(\mathbf{h}_{\mathbf{n}}^{2}\right)$ heritability of PRSVW resistance, according to Mather and Jinks (1977).

The additive [a] and non-additive [d] genetic effects that controls the resistance were estimated from generation means by the method of weighted least square (Mather and Jinks 1977). Also the average degree of dominance (ADD) and the minimum number of genes (h) controlling the resistance were estimated (Mather and Jinks 1977). The software SAS (Statistical Analysis System) was used in analysis (SAS Institute 2005).

\section{Distribution of frequencies and test for the hypothesis of monogenic inheritance}

The distribution of frequency of plants, based on scores for reaction to PRSV-W, were obtained for the parental Crimson Sweet $\left(\mathrm{P}_{1}\right)$ and PI $595201\left(\mathrm{P}_{2}\right)$, and also for the generations $\mathrm{F}_{1}, \mathrm{~F}_{2}, \mathrm{BC}_{11}$ e $\mathrm{BC}_{12}$. Data were used to test hypotheses of monogenic inheritance under different presumed average degrees of dominance
(ADD), as described by Gomes et al. (2000): a truncation point (TP) was established, above which were located most of the $\mathrm{P}_{1}$ (Sweet Charlie) plants and below which were most of the $\mathrm{P}_{2}$ (PI 595201) plants. The TP chosen was a score of $2(\mathrm{TP}=2)$. The assumptions and procedures used in this test are summarized as follows:

a) The data (scores = phenotypes) from all generations $\left(\mathrm{P}_{1}, \mathrm{P}_{2}, \mathrm{~F}_{1}, \mathrm{~F}_{2}, \mathrm{BC}_{11}\right.$, and $\left.\mathrm{BC}_{12}\right)$ were assumed to have a normal distribution;

b) The true means and variances of $\mathrm{P}_{1}$ and $\mathrm{P}_{2}$ were assumed to be equal to respective estimates obtained from experimental data;

c) Based on respective normal distribution, were estimated the expected frequencies of plants for P1 and P2 generations with scores less than or equal to the assumed truncation point $(\mathrm{TP}=2)$;

d) The true mean of $F_{1}$ generation was admitted to be $F_{1}=\left(\overline{\mathrm{P}}_{1}+\overline{\mathrm{P}}_{2}\right) / 2+\operatorname{ADD}\left(\overline{\mathrm{P}}_{1}+\overline{\mathrm{P}}_{2}\right) / 2$, where ADD is the presumed average degree of dominance under consideration. The true variance of the $F_{1}$ population was assumed to be equal to the respective variance from the experimental data.

e) Based on normal distribution of the $F_{1}$ population, were estimated the expected frequencies of plants for $\mathrm{F}_{1}$ with score values $\leq \mathrm{TP}$;

f) Under the hypothesis of monogenic inheritance, the expected frequencies of plant for $\mathrm{F}_{2} \leq \mathrm{PT}$ were calculated as the weighted average of the expected frequencies in $\mathrm{P}_{1}, \mathrm{~F}_{1}$ and $\mathrm{P}_{2}$, with weights 1:2:1, respectively;

g) Under the hypothesis of monogenic inheritance, the expected frequencies of plant for $\mathrm{BC}_{11}$ and $\mathrm{BC}_{12} \leq \mathrm{PT}$ were calculated as the weighted average of the expected frequencies in $\mathrm{P}_{1}$ and $\mathrm{F}_{1}$, with weights of $1: 1$, respectively for $\mathrm{BC}_{11}$; and the weighted average of the expected frequencies in $\mathrm{F}_{1}$ and $\mathrm{P}_{2}$, with weights of $1: 1$, respectively for $\mathrm{BC}_{12}$;

h) The expected number of plants $\leq \mathrm{TP}$ obtained for $\mathrm{P}_{1}$ and $\mathrm{P}_{2}$ (as estimated in "c"), $\mathrm{F}_{1}$ (as admitted in "d" and "e"), $\mathrm{F}_{2}$ (as calculated in "f"), $\mathrm{BC}_{11}$ and $\mathrm{BC}_{12}$ (as definited in "g"), were calculated by multiplying the expected frequencies by the total number of plants tested per generation, getting the expected frequencies of plants $\leq \mathrm{TP}$, under the hypothesis of monogenic inheritance with the considered average degree of dominance ADD;

i) The expected number of plants in $\mathrm{P}_{1}, \mathrm{P}_{2}, \mathrm{~F}_{1}, \mathrm{~F}_{2}$, $\mathrm{BC}_{11}$ and $\mathrm{BC}_{12} \leq \mathrm{TP}$ was compared with their respective 
SM Azevedo et al.

observed values in each generation. The significance of the deviations was estimated with a chi-square test $\left(\chi^{2}\right)$, with four degrees of freedom, as the expected frequencies of $\mathrm{P}_{1}$ and $\mathrm{P}_{2}$ were added in order to avoid expected frequencies equal to zero;

j) Significant $\chi^{2}$ values would lead to rejection of the hypothesis of monogenic inheritance under the presumed degree of dominance. On the other hand, nonsignificant $\chi^{2}$ values would lead to the acceptance of such a hypothesis. The values of $\chi^{2}$ for each ADD assumed were plotted against their respective hypothetical ADDs. The range of ADD values for which $\chi^{2}$ values fell below the critical $\alpha=0.05$ value represented the ADD range for which the hypothesis of monogenic inheritance could not be rejected.

\section{Genetic inheritance models and hypothesis tests of maximum likelihood}

Estimates of genetic parameters and their tests based on maximum likelihood method were obtained according to Gonçalves et al. (2004) and Rezende et al. (2004), considering data from third evaluation, to test the hypothesis of monogenic inheritance and/or the presence of polygenic loci controlling PRSV-W resistance. For the analyses, the full genetic model assumed a major gene with additive and dominance effects, and polygenes, also with additive and dominance effects. From the complete genetic model, simpler models containing less parameters were generated (Table 2). Environmental variances were considered equal for all generations, and gene segregation was considered independent (both major genes and polygenes). Hypotheses tests of the genetic parameters were performed based on the likelihood ratio between two models (Gonçalves et al. 2004). The tests were performed using the statistical software "Monogen v.0.1".

\section{RESULTSAND DISCUSSION}

\section{Estimates of genetic and phenotypic parameters}

Best results occurred in the third evaluation (49 days after first inoculation), in which the symptoms were clearly visible, allowing a more accurate assessment (Table 1). Also the errors associated with heritability in the third evaluation were $5 \%$ and $19 \%$ for $\mathrm{h}_{\mathrm{b}}^{2}$ and, $\mathrm{h}_{\mathrm{n}}^{2}$ respectively, indicating higher reliability of the parameters, while at the first evaluation these errors were $25 \%$ and $210 \%$ (Table 1). Thus, greater emphasis was given to the results of third evaluation.

The additive component [a] was higher than the non-additive [d] in the three evaluation times (Table 1). Estimates of ADD ranged from 0.5801 (indicative of incomplete dominance in the direction of great resistance to PRSV-W) in the first valuation date, to value close to zero $(0.0863)$ in the last evaluation (Table1), indicating additive gene action.

The highest estimate of the broad-sense heritability $(0.80)$ was obtained at third evaluation (Table 1 ), indicating that the genetic variance was greater than the environmental and that resistance to PRSV-W was little influenced by the environment, thus it was ideal to discriminate the genotypes. High estimated value for broad sense heritability agrees with the results of Vieira et al. (2010).

Estimate of narrow-sense heritability (0.67) in the third evaluation was near to that found for the broadsense heritability (0.80) (Table 1), allowing higher genetic gains in selecting more resistant plants in segregating populations and showing the greater importance of additive genetic variance in relation to non-addictive. The value of $[\mathrm{a}] /[\mathrm{d}](1.96 / 0.35=5.4)$ in the third evaluation indicates that the additive genetic effects contribute 5.4 times more to the resistance to PRSV-W, compared to non-additive genetic effects. The estimated number of genes was 2.61 (Table 1), indicating oligogenic or polygenic inheritance of the resistance.

Similar results regarding the type of inheritance to PRSV-W resistance were related by Maluf et al. (1985) in squash (Cucurbita maxima Duch), where resistance was also controlled by gene(s) with predominantly additive action. Maluf et al. (1997) related that the resistance to PRSV-W in squash (Cucurbita maxima Duch), lines ABL-10 and Redlands Trailblazer, is tolerance type and appears to be oligogenic. They observed that at least one of the loci involved in resistance of ABL-10 and Redlands Trailblazer is not common to both. Some susceptible plants occurred in $\mathrm{F}_{2}$ and $\mathrm{BC}_{11}$ (transgressive segregation) in the cross between resistant parents Redlands Tralblaser x ABL10 , indicating the non-allelism of resistance genes.

On the basis of our results, the resistance to PRSVW of the accession PI 595201 is also a tolerance type, because inoculum obtained from previously inoculated plants of PI 595201 plants was able to cause severe symptoms in plants of Cucurbita pepo cv. Asmara. Thus, plants of PI 595201, though not showing 
Inheritance of resistance to the Papaya ringspot virus-watermelon strain (PRSV-W) from watermelon accession 'pi 595201'

symptoms, are able to keep the viruses, but its multiplication rate appears to be small. For example, 23 days after inoculation, $100 \%$ of 'Asmara' plants showed symptoms (notes $=5.0$ ) when the inoculum was from 'Crimson Sweet', while only $20 \%$ of 'Asmara' plants were symptomatic (notes $=5.0$ ) when the inoculum was from PI 595201, indicating the difficulty in virus multiplication in plants of PI 595201. There was a slow increase in proportion of symptomatic plants of 'Asmara' inoculated from PI 595201, and 40 days after inoculation, there was only $50 \%$ of symptomatic plants. Similar results on effects of tolerance induction to PRSV-W were related in other cucurbits by other authors (Maluf and Souza 1984, Maluf et al. 1997).

Sittolin et al. (2000) reported that the resistance of watermelon 'BT 8501' to ZYMV and WMV was also oligogenic, like to PRSV-W resistance in the present study. Apparently, resistance to ZYMV and WMV in BT 8501 was controlled by the same genes.

Table 1. Generation means of PRSV-W score symptoms and its components $\mathrm{m}$, [a], [d], average degree of dominance (ADD); estimates of genetic $\left(\hat{\sigma}_{\mathbf{G}}^{2}\right)$, environmental $\left(\hat{\sigma}_{\mathbf{E}}^{2}\right)$, phenotypic $\left(\hat{\sigma}_{\mathrm{F} 2}^{2}\right)$, additive $\left(\hat{\sigma}_{\mathbf{A}}^{2}\right)$ and dominance $\left(\hat{\sigma}_{\mathbf{D}}^{2}\right)$ variances, and broad $\left(\mathbf{h}_{\mathbf{b}}^{2}\right)$ and narrow-sense $\left(\mathbf{h}_{\mathbf{n}}^{2}\right)$ heritabilities, and estimated number of genes $(\boldsymbol{\eta})$ for resistance to PRSV-W in watermelon

\begin{tabular}{|c|c|c|c|}
\hline Parameters & $\begin{array}{c}1^{\text {st }} \text { evaluation } \\
\text { (35 days after } \\
\mathbf{1}^{\text {st }} \text { inoculation) }\end{array}$ & $\begin{array}{c}2^{\text {nd }} \text { evaluation } \\
\text { (42 days after } \\
\mathbf{1}^{\text {st }} \text { inoculation) } \\
\end{array}$ & $\begin{array}{c}3^{\text {rd }} \text { evaluation } \\
\text { (49 days after } \\
1^{\text {st }} \text { inoculation) } \\
\end{array}$ \\
\hline$\overline{\mathrm{P}_{1}}=$ Crimson Sweet & 3.4177 & 4.0380 & 4.8354 \\
\hline$\overline{\mathrm{P}_{2}}=$ PI 595201 & 1.0941 & 1.1765 & 1.1882 \\
\hline$\overline{F_{1}}$ & 1.8795 & 2.6867 & 3.4458 \\
\hline$\overline{\mathrm{F}}_{2}$ & 1.8741 & 2.3522 & 3.0182 \\
\hline$\overline{B C_{11}}$ & 2.4551 & 3.2564 & 4.2628 \\
\hline$\overline{B C_{12}}$ & 1.2294 & 1.5529 & 1.7647 \\
\hline \multicolumn{4}{|l|}{ Means components } \\
\hline $\mathrm{m}$ & $2.1801 \pm 0.0962^{*}$ & $2.5155 \pm 0.1319^{*}$ & $2.9372 \pm 0.1838^{*}$ \\
\hline [a] & $1.1746 \pm 0.0948^{*}$ & $1.4853 \pm 0.1300^{*}$ & $1.9593 \pm 0.1811^{*}$ \\
\hline [d] & $0.4522 \pm 0.1781$ & $0.0122 \pm 0.2443$ & $0.3574 \pm 0.3403$ \\
\hline$\chi^{2}$ & 0.0768 & 0.0850 & 0.1129 \\
\hline ADD & 0.5801 & 0.1615 & 0.0863 \\
\hline \multicolumn{4}{|l|}{ Variances } \\
\hline$\hat{\sigma}_{\mathrm{G}}^{2}$ & 0.2713 & 0.4535 & 1.3036 \\
\hline$\hat{\sigma}_{\mathrm{E}}^{2}$ & 0.4240 & 0.5575 & 0.3202 \\
\hline$\hat{\sigma}_{\mathrm{A}}^{2}$ & 0.0760 & 0.2802 & 1.0883 \\
\hline$\hat{\sigma}_{\mathrm{D}}^{2}$ & 0.1953 & 0.1733 & 0.2153 \\
\hline $\mathbf{h}_{\mathrm{b}}^{2}$ & $\bullet 0.3901 \pm 0.1075$ & $0.4485 \pm 0.0736$ & $0.8028 \pm 0.0440$ \\
\hline $\mathrm{h}_{\mathrm{n}}^{2}$ & $0.1093 \pm 0.2145$ & $0.2771 \pm 0.1729$ & $0.6702 \pm 0.1315$ \\
\hline$\eta$ & 0.6338 & 0.9188 & 2.6169 \\
\hline
\end{tabular}


SM Azevedo et al.

Table 2. Genetic inheritance models and theirs parameters in the analysis of generations $\mathrm{P}_{1}, \mathrm{P}_{2}, \mathrm{~F}_{1}, \mathrm{~F}_{2}, \mathrm{BC}_{1}$ and $\mathrm{BC}_{2}$ according to Rezende et al. (2004) and Chi-square values $\left(\chi^{2}\right)$ for hypothesis tests of hierarchical genetic models about inheritance of the resistance to PRSV-W in watermelon

\begin{tabular}{|c|c|c|c|c|c|c|c|}
\hline $\begin{array}{c}\text { Genetic inheritance } \\
\text { Models }\end{array}$ & \multicolumn{3}{|c|}{ Major gene } & Polygenes & \multicolumn{3}{|c|}{ Genetic parameters } \\
\hline 1. Mixed inheritance & \multicolumn{3}{|c|}{ Additive and dominant } & Additive and dominant & \multicolumn{3}{|c|}{$\mathrm{m}, \mathrm{A}, \mathrm{D},[\mathrm{a}],[\mathrm{d}], \mathrm{v}_{\mathrm{A}}, \mathrm{V}_{\mathrm{D}}, \mathrm{S}_{\mathrm{AD}}, \sigma^{2}$} \\
\hline 2. Mixed inheritance & \multicolumn{3}{|c|}{ Additive and dominant } & Additive & \multicolumn{3}{|c|}{$\mathrm{m}, \mathrm{A}, \mathrm{D},[\mathrm{a}], \mathrm{V}_{\mathrm{A}}, \sigma^{2}$} \\
\hline 3. Mixed inheritance & \multicolumn{3}{|c|}{ Additive } & Additive and dominant & \multicolumn{3}{|c|}{$\mathrm{m}, \mathrm{A},[\mathrm{a}],[\mathrm{d}], \mathrm{V}_{\mathrm{A}}, \mathrm{v}_{\mathrm{D}}, \mathrm{S}_{\mathrm{AD}}, \sigma^{2}$} \\
\hline 4. Mixed inheritance & \multicolumn{3}{|c|}{ Additive } & Additive & \multicolumn{3}{|c|}{$\mathrm{m}, \mathrm{A},[\mathrm{a}], \mathrm{V}_{\mathrm{A}}, \sigma^{2}$} \\
\hline 5. Polygenic inheritance & \multicolumn{3}{|c|}{ 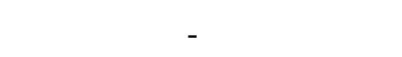 } & Additive and dominant & \multicolumn{3}{|c|}{$\mathrm{m},[\mathrm{a}],[\mathrm{d}], \mathrm{V}_{\mathrm{A}}, \mathrm{V}_{\mathrm{D}}, \mathrm{S}_{\mathrm{AD}}, \sigma^{2}$} \\
\hline 6. Polygenic inheritance & \multicolumn{3}{|c|}{-} & Additive & \multicolumn{3}{|c|}{$\mathrm{m},[\mathrm{a}], \mathrm{V}_{\mathrm{A}}, \sigma^{2}$} \\
\hline 7. Monogenic inheritance & \multicolumn{3}{|c|}{ Additive and dominant } & - & \multicolumn{3}{|c|}{$\mathrm{m}, \mathrm{A}, \mathrm{D}, \sigma^{2}$} \\
\hline 8.Monogenic inheritance & \multicolumn{3}{|c|}{ Additive } & - & \multicolumn{3}{|c|}{$\mathrm{m}, \mathrm{A}, \sigma^{2}$} \\
\hline 9. No genetic effects & \multicolumn{3}{|c|}{-} & - & \multicolumn{3}{|c|}{$\mathrm{m}, \sigma^{2}$} \\
\hline $\begin{array}{c}\text { Contrast between } \\
\text { models }\end{array}$ & df & $\chi^{2}$ & Probability & $\begin{array}{c}\text { Contrast between } \\
\text { models }\end{array}$ & df & $\chi^{2}$ & Probability \\
\hline 1 vs. 2 & 3 & * & $*$ & 3 vs. 5 & 1 & 67.18 & 0.000000189 \\
\hline 1 vs. 3 & 1 & * & $*$ & 3 vs. 6 & 4 & 81.70 & 0.000000297 \\
\hline 1 vs. 4 & 4 & 2.10 & 0.716894531 & 3 vs. 8 & 5 & 39.08 & 0.000000384 \\
\hline 1 vs. 5 & 2 & 51.98 & 0.000000190 & 3 vs. 9 & 6 & 804.56 & 0.000001819 \\
\hline 1 vs. 6 & 5 & 66.51 & 0.000000252 & 4 vs. 6 & 1 & 64.41 & 0.000000192 \\
\hline 1 vs. 7 & 5 & 7.59 & 0.179704178 & 4 vs. 8 & 2 & 21.79 & 0.000018657 \\
\hline 1 vs. 8 & 6 & 23.89 & 0.000546140 & 4 vs. 9 & 3 & 787.26 & 0.000001749 \\
\hline 1 vs. 9 & 7 & 789.36 & 0.000001829 & 5 vs. 6 & 3 & 14.52 & 0.002268916 \\
\hline 2 vs. 4 & 1 & 17.86 & 0.000023663 & 5 vs. 9 & 5 & 737.37 & 0.000001795 \\
\hline 2 vs. 6 & 2 & 82.27 & 0.000000353 & 6 vs. 9 & 2 & 722.85 & 0.000001508 \\
\hline 2 vs. 7 & 2 & 23.36 & 0.000008655 & 7 vs. 8 & 1 & 16.29 & 0.000054119 \\
\hline 2 vs. 8 & 3 & 39.65 & 0.000000237 & 7 vs. 9 & 2 & 781.76 & 0.000001903 \\
\hline 2 vs. 9 & 4 & 805.13 & 0.000001952 & 8 vs. 9 & 1 & $*$ & $*$ \\
\hline
\end{tabular}

m: cross mean; A: additive effect of the major gene; D: dominance effect of the major gene; [a]: additive effect of the polygenes; [d]: dominance effect of the polygenes; $\mathrm{V}_{\mathrm{A}}$ : polygene additive variance; $\mathrm{V}_{\mathrm{D}}$ : polygene dominance variance; $\mathrm{S}_{\mathrm{AD}}$ : sum of products of additivedominance effects products; $\sigma^{2}$ : environmental variance.

* negative value, probably due to convergence problems

Since ZYMV, WMV and PRSV-W are Potyvirus, and both the present results as those of Sittolin et al. (2000) reported similar estimates for the number of genes, it would be interesting to speculate on possible allelism relationships among genes controlling resistance to PRSV-W in PI 595201 and those that control resistance to ZYMV and WMV, as the possible effects of genes controlling resistance to PRSV-W in PI 595201 in order to also confer resistance to ZYMV and WMV.
Test of the hypothesis of monogenic resistance to PRSV$\mathrm{W}$ in watermelon

The phenotypic distribution of frequencies of generations $\mathrm{P}_{1}, \mathrm{P}_{2}, \mathrm{~F}_{1}, \mathrm{~F}_{2}, \mathrm{BC}_{11}$ and $\mathrm{BC}_{12}$ at third evaluation indicate that the inheritance of the resistance to PRSV-W on watermelon seems to be oligogenic or poligenic (Figure 1). The method used to test the hypothesis of monogenic inheritance was previously used by other authors (Gomes et al. 2000, Oliveira et al. 2003, Menezes et al. 2005). The values of $\chi^{2}$ related to 

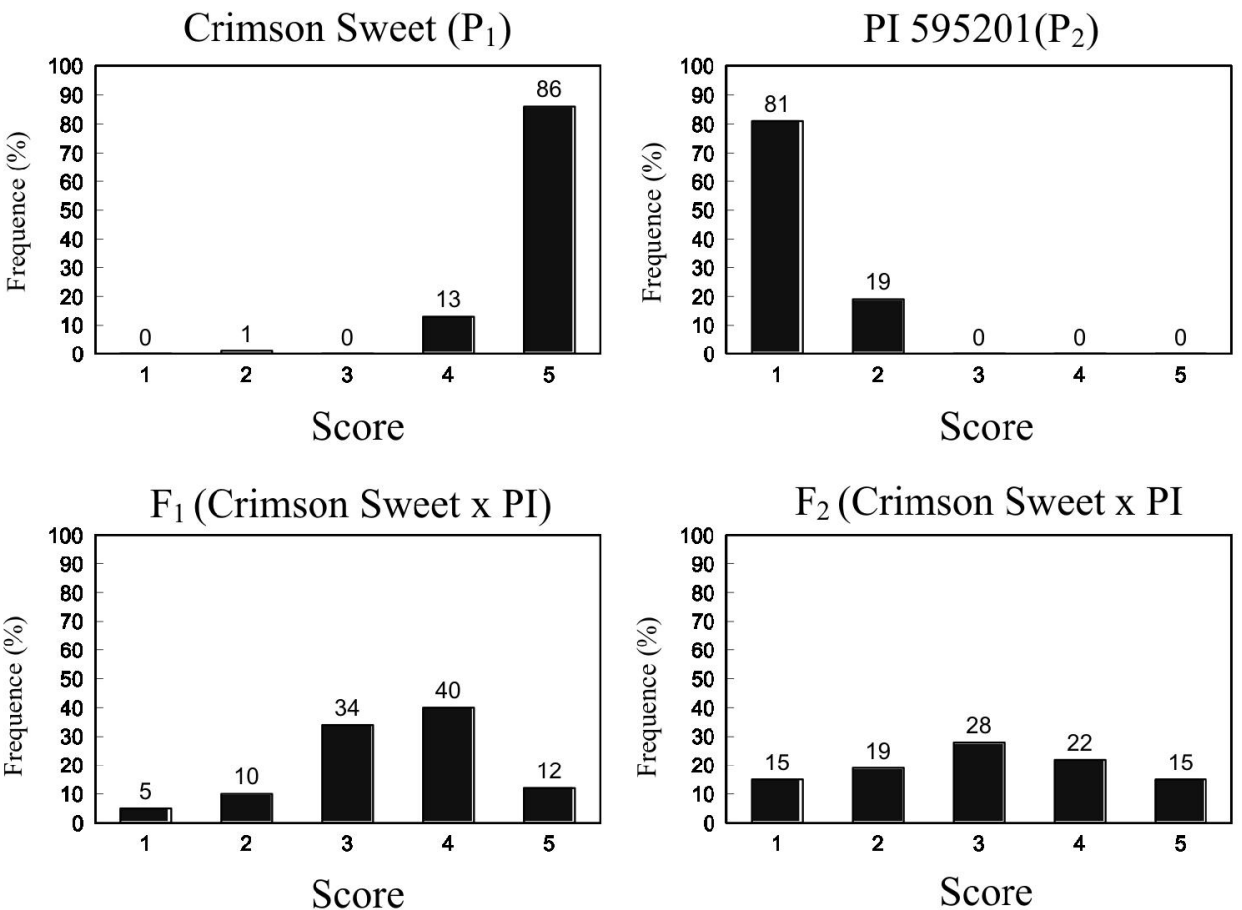

$\mathrm{BC}_{11}\left(\mathrm{~F}_{1} \times\right.$ Crimson Sweet $)$

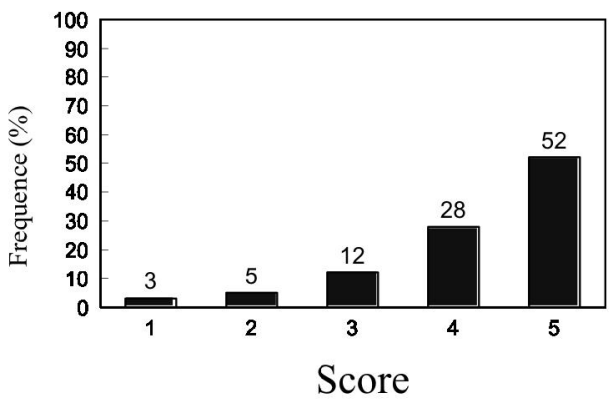

$\mathrm{BC}_{12}\left(\mathrm{~F}_{1} \times\right.$ PI 595201)

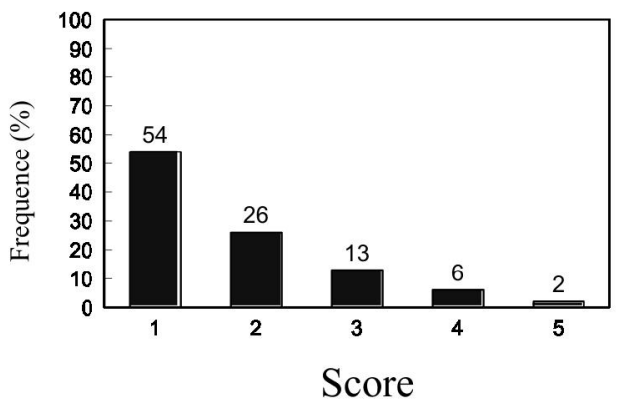

Figure 1. Distribution of frequencies for scores of reaction to PRSV-W infection on third evaluation (49 days after inoculation) in parental and generations from crossing between watermelon Crimson Sweet and PI 595201.

the hypothesis of monogenic inheritance were significant for all average degrees of dominance assumed in the two initial evaluations, as also for the third evaluation (Figure 2). This leads to the rejection of the hypothesis of monogenic inheritance for the resistance.

Resistance to PRSV-W in watermelon seems to be controlled by more than one gene. There are probably two to three loci involved in resistance control, according to estimate obtained in the third evaluation (Table 1). The number of genes and the predominantly additive mode of action are in accordance with results obtained by other authors (Maluf and Sousa 1984, Maluf et al. 1985, Herrington et al. 1989, Maluf et al. 1997) that studied the inheritance of resistance to PRSV-W in other cucurbits, such as C. maxima, C. ecuadorensis e $C$. moschata (Oliveira et al. 2003).

\section{Tests of genetic models using likelihood functions}

For data from the third evaluation date, the significance of hypothesis tests for the likelihood ratio between models 1 and 9 (Table 2) indicates that both a major gene and polygenes are involved in the control of the character, whereas the non-significance of the 
SM Azevedo et al.

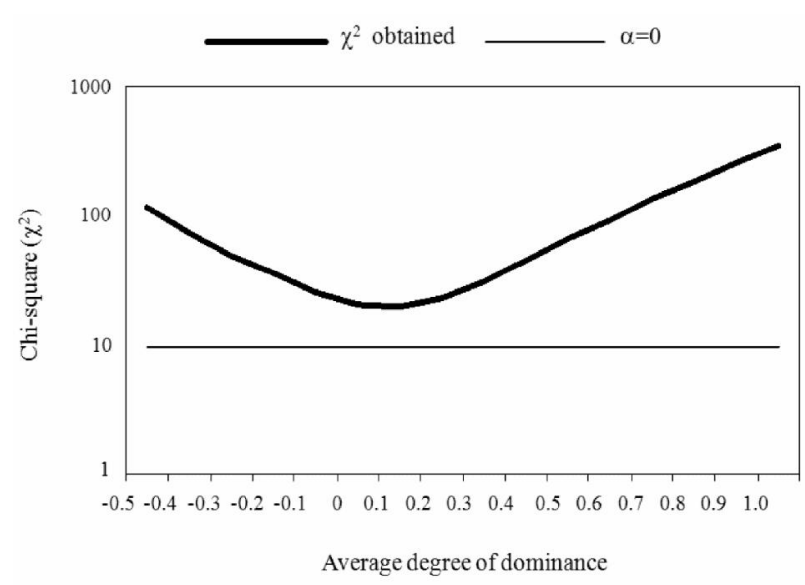

Figure 2. Values of $\chi^{2}$ observed for monogenic inheritance test, considering different presumed average degrees of dominance, for scores of reaction to PRSV-W in watermelon at third evaluation (49 days after inoculation).

test for comparisons between models 1 and 4 (Table 2) indicate that neither for the major gene nor for the polygenes were dominance effects important. The importance of additive effects both for the major gene and for the modifier polygenes were further reinforced by the significance of the comparisons between models
4 vs 6 and 4 vs 8 (Table 2). The importance of the additive genetic effects in the expression of resistance to PRSV$\mathrm{W}$ can be further emphasized by the fact that $\mathrm{F}_{1}(3.4458)$ and F2 (3.0182) generation means were close to the mean of the parents (3.0118) in the third evaluation, ant that the estimated average degree of dominance was close to zero (Table 1).

The combining findings of the test of monogenic inheritance and the maximum likelihood point out a mode of inheritance that is more complex than could be expected from a typical monogenic inheritance. Even though the maximum likelihood tests indicate that a locus with major genetic effects is present, that locus alone could not account for all the genetic variation. This conclusion is in accordance with the findings of of the monogenic inheritance test and does not contradict the estimates obtained for the number of genes involved (Table 1).

\section{ACKNOWLEDGEMENTS}

The authors acknowledge the agencies and companies in Brazil that supported this research project: CNPq/RHAE, FAPEMIG, CAPES/MEC, UFLA/FAEPE and HortiAgro Sementes Ltda.

\title{
Herança da resistência ao Papaya ringspot virus-watermelon strain (PRSV-W) proveniente do acesso de melancia 'PI 595201'
}

\begin{abstract}
Resumo - Dois genótipos de melancia foram cruzados para estudar a herança da resistência ao Papaya ringspot virus estirpe melancia (PRSV-W): a cultivar Crimson Sweet (suscetível) e o acesso 'PI 595201' (resistente). As plantas das gerações $P_{1}, P_{2}, F_{1}, F_{2}, B C_{11}$ e $B C_{12}$ foram inoculadas com um isolado brasileiro do $P R S V$-W e os sintomas foram avaliados. Foram estimados parâmetros genéticos e fenotípicos da resistência ao $P R S V-W$ e foram realizados os testes de hipótese de herança monogênica e de máxima verossimilhança. $O$ componente aditivo [a] da resistência foi maior do que os não-aditivos [d]. As estimativas da herdabilidade no sentido amplo $(0,80)$ e restrito $(0,67)$ indicaram que a variância genética foi superior à ambiental, permitindo maiores ganhos genéticos na seleção de plantas resistentes em populações segregantes. Os resultados indicam uma herança mais complexa do que a monogênica típica. Ficou evidente a importância dos efeitos gênicos aditivos no controle da resistência ao PRSV-W.
\end{abstract}

Palavras chave: Citrillus lanatus, grau de dominância, herdabilidade, potyvirus, resistência a vírus. 
Inheritance of resistance to the Papaya ringspot virus-watermelon strain (PRSV-W) from watermelon accession 'pi 595201'

\section{REFERENCES}

Araújo JP and Souza RC (1988) Avaliação de germoplasma de melancia com provável resistência mecânica ao vírus WMV-1 em Petrolina (PE). Horticultura Brasileira 6: 45 .

Bateson MF, Lines RE, Revill P, Chaleeprom W, Ha CV, Gibbs AJ and Dale JL (2002) On the evolution and molecular epidemiology of the potyvirus papaya ringspot virus. Journal of General Virology 83: 2575-2585.

Fraser RSS (1992) The genetics of plant-virus interactions: implications for plant breeding. Euphytica 63: 175-185.

Gomes LAA, Maluf WR and Campos VP (2000) Inheritance of the resistant reaction of the lettuce cultivar 'Grand Rapids' to the southern root-knot nematode Meloidogyne incognita (Kofoid and White) Chitwood. Euphytica 114: 37-46.

Gonçalves RP, Bearzoti E and Ferreira DF (2004) Avaliação da razão de verossimilhança generalizada em teste de hipóteses sobre o controle genético de características contínuas. Semina Ciências Agrárias 25: 281-292.

Herrington ME, Byth DE, Teakle DS and Brown PJ (1989) Inheritance of resistance to papaya ringspot virus type $\mathrm{W}$ in hybrids between Cucurbita ecuadorensis and C. maxima. Australian Journal of Experimental Agriculture 29: 253259.

Hojo H, Silva N and Pavan MA (1991) Triagem de cultivares e híbridos de melancia para resistência ao vírus do mosaico do mamoeiro - estirpe melancia (VMM-Me). Summa Phytopathologica 17: 113-118.

Maluf WR, Pereira JJ and Figueira AR (1997) Inheritance of resistance to the papaya ringspot virus-watermelon strain from two different accessions of winter squash Cucurbita maxima Duch. Euphytica 94: 163-168.

Maluf WR, Silva IS and Moura WM (1985) Inheritance of watermelon mosaic virus-1 (WMV-1) resistance in squash Cucurbita maxima Duch. Revista Brasileira de Genética 8: $175-182$.

Maluf WR and Sousa ELS (1984) Resistência ao vírus do mosaico da melancia-1 (WMV-1) em moranga. Horticultura Brasileira 2: 22-25.

Mather K and Jinks JL (1977) Introduction to biometrical genetics. Cornell University Press, Ithaca, 213p.

Menezes CB, Maluf WR, Azevedo SM, Faria MV, Nascimento, IR, Nogueira DW, Gomes LAA and Bearzoti (2005) Inheritance of parthenocarpy in summer squash (Cucurbita pepo L). Genetics and Molecular Research 4: 39-46.
Nascimento IR, Santos LB, Figueira AR, Santos GR, Aguiar RWS, Maluf WR and Oliveira1 GIS (2011) Identificação molecular de espécies de vírus e reação fenotípica de famílias de melancia a um isolado do vírus da mancha anelar do mamoeiro, estirpe melancia (Pappaya ringspot virus - strain watermelon - PRSV-W) Journal of Biotechnology and Biodiversity 2: 22-29.

Oliveira ACB, Maluf WR, Pinto JEBP and Azevedo SM (2003) Resistance to papaya ringspot virus in summer squash Cucurbita pepo L. introgressed from a interspecific $C$. pepo x $C$. moschata cross. Euphytica 132: $211-215$.

Pitrat $\mathrm{M}$ and Lecoq $\mathrm{H}$ (1983) Two alleles for watermelon mosaic virus 1 resistance in melon. Cucurbit Genetics Cooperative Reports 6: 52-53.

Rezende JAM and Pacheco DA (1998) Control of papaya ringspot virus-type $w$ in zucchini squash by crossprotection in Brazil. Plant Disease 82: 171-175.

Rezende VF, Vencovsky R, Cárdenas FEN, Silva HP, Bearzoti E and Camargo LEA (2004) Mixed inheritance model for resistance to anthracnose leaf blight in maize. Crop Breeding and Applied Biotechnology 4: 115-122.

Sas Institute (2005) SAS. Version 9.1, SAS, Cary (CDROM).

Sittolin IM, Pavan MA and Silva N (2000) Inheritance of tolerance of watermelon to zucchini yellow mosaic virus and watermelon mosaic virus-2. Summa Pytopathologica 26: 210-214.

Strange EB, Guner N, Pesic-VanEsbroeck Z and Wehner TC (2002) Screening the watermelon germplasm collection for resistance to Papaya ringspot virus type-W. Crop Science 42: 1324-1330.

Vieira JV, Ávila AC and Silva GO (2010) Avaliação de genótipos de melancia para resistência ao Papaya ringspot vírus, estirpe melancia. Horticultura Brasileira 28: 7-11.

Wai T and Grumet R (1995) Inheritance of resistance to the watermelon strain of Papaya ringspot virus in the cucumber line TMG-1. HortScience 30: 338-340.

Wang YJ, Providenti R and Robinsin RW (1984) Inheritance of resistance to watermelon mosaic virus-1 in cucumber. HortScience 19: $587-588$ 